\title{
Vienna Letter to Sultan Mehmed IV Avji from Ukrainian Cossaks in Chyhyryn
}

\author{
Taras Chuhlib ${ }^{1}$
}

'Corresponding author/Sorumlu yazar: Taras Chuhlib (Prof. Dr.), Institute of History of Ukraine National Academy of Sciences, Kyiv, Ukraine.

E-posta: taras_chuhlib@ukr.net ORCID: 0000-0002-2604-4816

Submitted/Başvuru: 20.09.2020 Revision Requested/Revizyon Talebi: 13.12.2020

Last Revision Received/Son Revizyon: 20.12.2020

Accepted/Kabul: 15.03 .2021

Citation/Atıf: Chuhlib, Taras, "Vienna Letter to Sultan Mehmed IV Avji From Ukrainian Cossaks in Chyhyryn", Güneydoğu Avrupa Araștırmaları Dergisi, 35 (2020), s. 89-96. https://doi.org/10.26650/gaad.797502

\section{ABSTRACT}

The article explores the genesis of writing, as well as the problem of spreading a semi-legendary message called "Letter of the Cossacks to the Turkish sultan." The study of "correspondence of the Cossacks with the Sultan" has a long historiographical tradition, in particular, the Russian historian and literary critic M. Kagan has developed 9 manuscript lists of this correspondence. The first "Letter of the Cossacks..." in the Old Ukrainian language was published in 1843 by Mykola Markevych. The author studies the issue of the appearance of Chyhyryn's "Letter of the Cossacks from Chyhyryn to the Turkish Sultan" in Vienna in 1683 in the form of a "flying leaf", which had a specific historical basis. It is known that the Ottoman Empire and the Crimean Khanate, trying to prevent the recruitment of Cossacks to the army of the King of the Commonwealth Jan III Sobieski, sent letters to Ukraine and the Zaporozhian Sich with a call to submit to the sultan or khan. The researcher concluded that this "leaflet" served a dual patriotic and propagandistic function: first, it raised the morale of the defenders of Vienna, and, secondly, influenced the Cossack officers of Ukraine to support the antiOttoman coalition of Christian European states. In addition, the army of the Grand Vizier Kara Mustafa remembered very well the exhausting Chyhyryn campaigns of 1677 and 1678 to Ukraine, which became good training for the Ottoman Empire before the campaign in Vienna, Austria. A new Polishlanguage version of the "Letter of the Cossacks..." from the archives of Poland is introduced into scientific circulation..

Keywords: Ottoman Empire, Zaporozhian Army, "Letter of the Cossacks", Chyhyryn, Mehmed IV, Jan III Sobieski, Ivan Sirko 
During the struggle of the Christian coalition of European states with the Ottoman army of Grand Vizier Kara Mustafa in the summer and autumn of 1683, a very interesting "leaflet" began to spread among the inhabitants of Vienna and other European cities. One of the versions of this leaflet, which is kept in the funds of the National Library of Vienna, is entitled «Copia des Turckischen Kaysers Brieff an die Kosacken nach Czechrin. Gedruckt im Jahr 1683». The other two variants that survived had similar names: «Copia des Türckischen Käysers Brieff an die Cosacken nach Czechrin und darauff der Cosacken Antwort. Dabey aus Venedig was die Brieffe von Constantinopel melden» та «Copia des Türkischen Kaysers Brief an die Cosacken

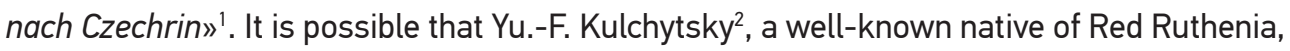
was involved in its publication and translated into German the "Letter of the Cossacks from Mykola Markevych to the Turkish Sultan."3

Ukrainian literary critic Hryhorii Nudha has studied the genesis of writing, for a long time as well as the problem of spreading this legendary message ${ }^{4}$. In addition, the study of "correspondence between the Cossacks and the Sultan" has a long historiographical tradition", and the Russian historian and literary critic M. Kagan has developed 9 manuscript lists of this legendary correspondence from the archives of Russiab. The "Letter of the Cossacks..." was first published in the Old Ukrainian language in 1843 by Mykola Markevych in the "History of Little Russia" with a note that the reprint was made from a copy sent "from the particular archive" of the Belarusian city of Grodno7. In 1845, the St. Petersburg magazine "Mayak" published on its pages "Letter of the Chyhyryn Cossacks to the Turkish Sultan." In 1869, 0. Popov analyzed one of the lists of the "Letter of the Cossacks", which was included in the Chronograph in 1696. ${ }^{9}$ And in 1872, one of the versions of the correspondence, which belonged to M. Kotsomarov, was published in "Russian Antiquity"10. In 1874 0.Petrushevych published

1 The originals of these "flyers" are kept in the library of the Saxon city of Wolfenbüttel (Germany), and their electronic copies in the Polish electronic library "Digital Library of Polish and Poland-Related News Pamphlets from the 16 th to the 18 th Century" (http: // cbdu. id.uw.edu.pl/).

2 I. Micko, T. Paslavskij, «Yurij-Franc Kulchickij - geroj oboroni Vidnya», Lviv, 2013, p.38.

3 In Ukraine it was published by Hryhoriy Nudha (G. Nudga, «Na literaturnih shlyahah (doslidzhennya, poshuki, znahidki)», K.,1990. p.303 - 306). See also: T. Chuhlib, «Viden 1683. Ukrayina-Rus u bitvi za «zolote yabluko» Yevropi», K.,2013, p.376 - 377.

4 G. Nudga, «Parodiya v ukrayinskij literaturi», K.,1961, p. 65; He is. G. Nudga, «List zaporozhciv tureckomu sultanu», Dnipro, 1962, №2, p.141; He is. G. Nudga, «Listuvannya zaporozhciv z tureckim sultanom», K.,1963;

5 K. Harlampovich, «Listuvannya zaporozkih kozakiv iz sultanom», Zapiski Istorichno-filologichnogo viddilu VUAN, K.,1923, Kn. IV, p.200 - 212; E. Borschak, «La letter des zaporogues au sultan», Revue des etudes slaves, Paris, 1950, T.26, p. $99-105$.

6 M. Kagan, «Russkaya versiya 70-h godov XVII v. perepiski zaporozhskih kazakov s tureckim sultanom», Trudy otdela drevnerusskoj literatury Instituta literatury AN SSSR, Moskva,1958, T.14, p.307 - 315; M. KaganTarkovskaya, «Perepiska zaporozhskih i chigirinskih kazakov s tureckim sultanom (v variantah XVIII v.)», Trudy ODRK Pushkinskogo Doma, AN SSSR, M-Leningrad, 1966, T. XXI, p.346 - 354.

7 N. Markevich, «Istoriya Malorossii», Moskva, 1843, T.V, Primechaniya k glave XLI, p.74 - 75.

8 Mayak, SPb.,1845, T.22, Smes, p.112- 113.

9 A. Popov, «Izbornik slavyanskih i russkih sochinenij i statej, vnesennih v hronografi russkoj redakcii», M.,1869, p.448.

10 Russkaya starina, SPb.,1872, T.VI, p. 450 - 451. 
the text "Letter of the Cossacks..." in Lviv"1. In 1879, 0. Prozorovskii found a document entitled "Translation from the Polish alphabet, a list from the letter of the Turkish sultan, written in Chigirin to the Cossacks on July 7, 1678", which dates to the late 1670's. ${ }^{12}$ After that, he was repeatedly popularized by D. Yavornytsky. ${ }^{13}$ A well-known collector of Cossack antiquity, the ethnographer J.Novitsky at the end of the nineteenth century recorded a legend about the correspondence of the Cossacks with the sultan from a resident of the village of Novogupalivka near Zaporozhye. ${ }^{14}$ In 1913, M. Ogloblin found the manuscript "Letter of the Cossacks...", dated 1733 in the collection of the Kiev-Pechersk Lavra. ${ }^{15}$

Despite the great historiographical tradition, the history of the origin and writing of the "Letter of the Cossacks “ remained mysterious. Researchers could not agree on the origin of this document. Although already in the handwritten Cossack chronicle, which according to Samiilo Velychko was recorded in Pereyaslav in 1636, there was talk of "non-political" correspondence, but not between the Cossacks and the sultan, but between the Turkish and Polish monarchs. There is a seemingly true letter of Sultan Osman II to the King of the Commonwealth, Sigismund III Vaz: “... you have our advice for nothing, and you want to snatch the land of Jerusalem from our power; although you are an insignificant person and then you have an unjust intention. Fear death with those little ones of yours, when I will deliberately and clearly encroach on your kingdom; and then everything will be as I want. Understand my power ${ }^{16}$. Instead, in the letter of reply of the King of the Commonwealth, quoted by Samiilo Velychko, there is a certain mockery: "But we hope, with the help of my Christian God, that the Polish eagle in a short time in Constantinople will curse Muhammad and you with fire. turn to ashes, for I know the time of the death of your accursed one"17.

It is obvious that it was under the influence of this humorous pamphlet by a Polish chancellor that one of the scribes of the Zaporozhian Army came up with the idea to make a parody letter 45,000 Cossacks fought on the side of King Sigismund III Vaz near Khotyn (Hetman Konashevych-Sahaidachny). Which would support the morale of the Cossacks. In the same year, 1621, in one of the Polish "flyers" the course of the battle of Khotyn was reported and the message of the Turkish sultan to the Polish king with the corresponding titles was published. ${ }^{18}$

11 A. Petrushevich, «Svodnaya galicko-russkaya letopis s 1600 po 1700 god», Lvov, 1874, p.361 - 362.

12 D. Prozorovskii, «Opis drevnih rukopisej, hranyashihsya v muzee imeratorskogo Russkogo arheologicheskogo obshestva», SPb.,1879, p.66- 67.

13 D. Evarnickii, «lvan Dmitrievich Serko, slavnyj koshevoj ataman vojska zaporozhskih i nizovyh kazakov», SPb.,1895, p. 97 - 98.

14 Letopis Ekaterinoslavskoj uchenoj arhivnoj komissii, Ekaterinoslav,1911, Vyp.7, p.113-116.

15 "Chtenie v Obshestve istorii i drevnostej Rossijskih», M.,1913, Kn.3, Smes, p.10.

16 S. Velichko, «Letopis sobytij v Yugo-zapadnoj Rossii v XVII v», K., 1848, p.3 - 5 (Prilozhenie).

17 lbid.

18 M. Kagan, «Russkaya versiya 70-h godov XVII v. perepiski zaporozhskih kazakov s tureckim sultanom», Trudy otdela drevnerusskoj literatury Instituta literatury AN SSSR, Moskva,1958, T.14, p.348. 
In the Moscow manuscript "newspapers-chimes" for 1621, this information was immediately rewritten: "Translations from statements sent from Poland about various military actions and peace decrees in Europe, and from whom they were sent - are not specified. From the city of Gdansk, the deeds say that the Turkish king sent such a letter of denial to the king: the king in Alexandria and in Judea, over Portugal, and all the emperors of all the earth and the sovereign of the aspiration of the lands, the guardian of the Busurman paradise and the holy tomb $»^{19}$.

The Russian archives also contain a "large letter" of the Turkish sultan to the Polish king, dated 1637. The document states: "Translation from the German script that a list is written from a letter sent by the Turkish king to the Polish king 146 (1637). The letter of refusal of the Turkish tsar to his royal majesty was sent to Poland. And it was translated from Turkish into Polish, and from Polish into German, and from German into our Slovenian. "20 Among other things, this document wrote about the Polish "his reeds, Zaporozhian Cossacks, like running greedy dogs, released our monarchy and the state to plunder and ravage people and our land by your order and command."21

Several other legendary and parody letters from the correspondence of the Turkish sultan (but no longer with the Polish king, but with "German rulers and all Christian people" and the Austrian emperor Leopold I) date from 1663. They were directly related to military and political struggle between the Habsburgs and the Ottomans, which unfolded at that time in Central and Eastern Europe. At the same time, an unknown author put the following words into the mouth of Mehmed IV Avji: "I will come to visit you and all your Polish allies and all your forces with our troops, we will ruin and disperse with murders and ruins, but also with death, which we can invent, torture and destroy, and we order all your captives to be beaten and tortured to death or in terrible prisons, to timed their heart out. "22 And "Leopold I" replied to the sultan that "it is stupider, you guard the button of the tomb of Christ my God, you write, being sane, but not to brag about that, to be torn, we know that it is good for you to wallow in dogs, to guard the king's courts and the doors of emperors." Like a mosque to them on a piece of bread to the lips. ${ }^{23}$

Another legendary pamphlet of the sultan to the Polish king dates back to 1678. In it, Mehmed IV the Hunter rebuked the King of the Commonwealth Jan III Sobieski for inciting

19 The Sultan's message to the Polish king from the chimes of 1621 / Appendix to the texts of the cycle of letters // M. Kagan, «Legendarnyj cikl gramot tureckogo sultana k evropejskim gosudaryam - publicisticheskoe proizvedenie vtoroj poloviny XVII v.», Trudy otdela drevnerusskoj literatury Instituta literatury AN SSSR, Moskva, 1959, T.15. p.249 - 250 .

20 M. Kagan, «Legendarnyj cikl gramot tureckogo sultana k evropejskim gosudaryam - publicisticheskoe proizvedenie vtoroj poloviny XVII v.», Trudy otdela drevnerusskoj literatury Instituta literatury AN SSSR, Moskva, 1959, T.15. p.241.

21 Ibid. - P.241 - 242.

22 lbid. - P. 245.

23 Ibid. - P.249. 
the Ukrainian Cossacks to war with the Ottoman Empire: "Ukrainian Cossacks as rabid dogs ruin and devastate. " ${ }^{24}$ In 1670, another interesting letter from Mehmed IV Avji to "German princesses , Polish kings, the Pope, cardinals, bishops and all Christians". It was translated from the "German script" and preserved in one of the manuscript lists of the Muscovy, and later found its way into the notes of I. Zhelyabuzhsky. The latter pointed out that this message was written by him from the Ambassadorial Order as "a list from a letter written from a letter of the Turkish sultan to Emperor Leopold, as written by the Turkish sultan." ${ }^{25}$

Thus, it is probable that the "Letter of the Cossacks..." was still of "Polish" or "German" origin and strangely returned to German-speaking Vienna. The only original copy of this message has not been found, but its numerous versions are known, which are dated to different years $(1600,1619,1620,1667,1672,1677,1683$, etc.) and along with different signatures "grassroots Cossacks", "Otaman Zakharchenko", "Ivan Sirko", they have different recipients Sultans "Osman", “Mehmed IV", "Ahmed III" and so on. In fact, it is known about the diplomatic correspondence of Cossack rulers with the rulers of other countries, including the Turkish sultan, has a completely different character and never violated the etiquette of the time to address a person of this level. Another confirmation of the "literary version" is the presence of numerous options for the sultan to address the Cossacks. Despite its literary origins, this ideological weapon was used by the Ukrainian Cossacks many times.

Well-known researcher Dmytro Yavornytsky linked the emergence of correspondence with the activities of the longtime camp commander (otaman) Ataman of the Zaporozhian Sich, Ivan Sirko. In particular, with the episode when in the winter of 1674 a 40,000-strong Tatar horde and 15,000 Turkish janissaries tried to insidiously seize the military garrison in the Sich. Successfully withstanding the night attack, the Cossacks defeated the TurkishTatar units. The following year, led by Otaman I.Sirko, they took revenge on the conquerors: a 20,000-strong Cossack army marched victoriously into the Crimea. During this campaign Sirko wrote a letter to the Crimean khan, filled with great irony and sarcasm: “... We, following the example of our ancient ancestors and brothers, decided to try to pay for dinner and sorrow, and to take revenge on your Khan's Mercy and the whole Khanate. but not secretly, as you did, but openly, like a knight ... "26. As we can see, the text of this real letter differed significantly from the parody message of the Cossacks, although, apparently, was influenced by its famous predecessor.

After the siege of Kamianets-Podilskyi by the Ottoman army in 1672, another version of the sultan's satirical message appeared, which was already used during the Turkish campaign of 1674 to Ladyzhyn and Uman and, apparently, was to raise the fighting spirit of the defenders

24 A. Sobolevskii, «Perevodnaya literatura Moskovskoj Rusi XIV - XVIII vekov», SPb.,1903, p.239.

25 «Sobranie raznyh zapisok i sochinenij, sluzhashih $k$ dostavleniyu polnogo svedeniya o zhizni i deyaniyah Petra Velikogo», Izd. F. Tumanskim, Cpb.,1787, Ch.VII. p.161 - 163.

26 Quote for: D. Evarnickii, «Ivan Dmitrievich Serko, slavnyj koshevoj ataman vojska zaporozhskih i nizovyh kazakov», $\mathrm{SPb} ., 1895, \mathrm{p} .95$. 
of these cities. The "Letter of the Cossacks ..." also played a role during the campaigns of thousands of Ottoman troops on Chyhyryn in 1677 and 1678. ${ }^{27}$ In a document entitled "List from a letter sent to Chyhyryn to the Cossacks by the Turkish sultan on the 7th day of 1678 "Was placed as if the address of Megmed IV the Hunter to the defenders of the capital of the Ukrainian Hetmanate: prince of princes, grandson of God, brave warrior, Christian persuader, guardian of the crucified God, great lord, lord on earth, hope and consolation of Busurman, sorrow and fall for Christians. We command you to surrender voluntarily with all people. ${ }^{28}$ "To which the Cossacks responded in a note entitled "Excuse the answer from Chyhyryn to the Sultan": "The Sultan, the accursed Turkish Sultan's comrade, Satan of the abyss of hell, the Sultan of Turkey, the Greek footstool, the cook of Babylon, the armor of Jerusalem, the chariot of Assyria Alexandrian swineherd, Armenian argach, Tatar dog, cursed asp living in the world, kidnapper of Kamianets-Podilskyi and all earthly subjects spin and miser, and the whole world of ghosts, Turkish county busurmany, equal to the revolt, protégé of Satan, Satan's messenger cursed, God's crucified enemy and persecutor of his servants, the hope and consolation of Busurman, their fall and sorrow. We will not give in to you, but we will fight with you. "29 Later, this text appeared in the manuscript book "Flower Garden", which from the end of the 17th century, according to the Galician historian 0 . Petrushevych, was stored in the Vienna court library. ${ }^{30}$

However, not the most important merit of the unknown authors of this ancient Ukrainian parody was the fact of its influence on the victory of the European coalition over the army of the Grand Vizier of the Ottoman Empire Kara Mustafa in 1683. It is unknown who, how and when brought the text of the parody to distant Vienna, offered to translate it into German and distribute it in a separate leaflet, but, as they say, the fact remains: for the first time in printed form the message of the Cossacks to the Turkish sultan was published in 1683 in Austria in the form of a "flyer".

On the pages of the Viennese edition there are two texts - "A copy of the letter of the Turkish sultan to the Cossacks in Chyhyryn" and the actual "Answer of the Cossacks". Given that Chyhyryn is mentioned here, we can assume that the Austrian edition repeated the text that was distributed among the defenders of the Cossack capital in 1678. At the same time, the Viennese copy of the message was significantly revised by an anonymous author, given the situation at the time: "Turkish emperor's son, ... you sit in a hole like a devil, or a hen-thief, who changes his nest in the war to another, one which shows that you are a fool, instead of the one you call a paholk (King Jan III Sobieski. - T.Ch.), is a brave, powerful monarch and

27 M. Kagan, «Russkaya versiya 70-h godov XVII v. perepiski zaporozhskih kazakov s tureckim sultanom», Trudy otdela drevnerusskoj literatury Instituta literatury AN SSSR, Moskva,1958, T.14, p.314 - 316.

28 This text was first published in the publication: A. Petrushevich, «Svodnaya galicko-russkaya letopis s 1600 po 1700 god», Lvov, 1874 , p.361 - 362.

29 A. Petrushevich Decree. op. - P.362.

30 See: «Tisyacha rokiv ukrayinskoyi suspilno-politichnoyi dumki. U 9-ti tomah», K.,2001, T.2. 
invincible king ${ }^{31}$. The last words suggest that the "flyer" was issued after the Commonwealth troops arrived near Vienna, and, consequently, the "flyer" was issued in the period from the second half of September to December 1683. Recently, in the archives of Poland a hitherto unknown Polish-language letter signed by the "Cossacks of Zaporozhya and all of Ukraine" was found. ${ }^{32}$ It is dated August 24, 1683, but, apparently, was again written after the Vienna campaign by the royal chancellors in order to further glorify Jan III Sobieski.

The appearance of Chyhyryn's "Letter of the Cossacks from Chyhyryn to the Turkish Sultan" in Vienna in 1683 in the form of a "flying leaf" also had a specific historical basis. It is known that the Ottoman Empire and the Crimean Khanate, trying to prevent the recruitment of Cossacks to the army of King Jan III Sobieski, sent letters to Ukraine and the Zaporozhian Sich with a call to submit to the sultan or khan. It is possible that in this way this "leaflet" served a dual patriotic and propagandistic function: first, it raised the morale of the defenders of Vienna, and, secondly, influenced the Cossack officers of Ukraine to support the anti-Ottoman coalition of Christian European states. In addition, the army of the Grand Vizier Kara Mustafa remembered very well the exhausting Chyhyryn campaigns of 1677 and 1678 to Ukraine, which became good training for the Ottoman Empire before the campaign in Vienna, Austria.

Peer-review: Externally peer-reviewed.

Conflict of Interest: The author has no conflict of interest to declare.

Grant Support: The author declared that this study has received no financial support.

Hakem Değerlendirmesi: Dış bağımsız.

Çıkar Çatışması: Yazar çıkar çatışması bildirmemiştir.

Finansal Destek: Yazar bu çalışma için finansal destek almadığını beyan etmiştir.

\section{Bibliography}

A. Petrushevich, «Svodnaya galicko-russkaya letopis s 1600 po 1700 god», Lvov, 1874

A. Popov, «lzbornik slavyanskih i russkih sochinenij i statej, vnesennih v hronografi russkoj redakcii», M., 1869, p.448.

A. Sobolevskii, «Perevodnaya literatura Moskovskoj Rusi XIV - XVIII vekov», SPb.,1903, p.239.

Biblioteka Polskoyi Akademiyi nauk u Krakovi, Viddil rukopisiv, Ruk.243, ark.14-16.

«Chtenie v Obshestve istorii i drevnostej Rossijskih», M.,1913, Kn.3, Smes, p.10.

«Copy of the Turkish Kaysers Brieff in the Kosacken to Czechrin. Gedruckt im Jahr 1683», Vienna National Library.

D. Evarnickii, «Ivan Dmitrievich Serko, slavnyj koshevoj ataman vojska zaporozhskih i nizovyh kazakov», $\mathrm{SPb} ., 1895$.

31 Quote for: Boredom G. Instruction. labor. - P.305.

32 Biblioteka Polskoyi Akademiyi nauk u Krakovi, Viddil rukopisiv, Ruk.243, ark.14-16. 
D. Prozorovskii, «Opis drevnih rukopisej, hranyashihsya v muzee imeratorskogo Russkogo arheologicheskogo obshestva», SPb.,1879, p.307.

E. Borschak, «La letter des zaporogues au sultan», Revue des etudes slaves, Paris, 1950, T.26, p. 99 - 105. Hryhorii Nudha, «List zaporozhciv tureckomu sultanu», Dnipro, 1962, №2, p.141.

Hryhorii Nudha, «Listuvannya zaporozhciv z tureckim sultanom», K.,1963.

Hryhorii Nudha, «Na literaturnih shlyahah (doslidzhennya, poshuki, znahidki)», K.,1990. p.303 - 306.

Hryhorii Nudha, «Parodiya v ukrayinskij literaturi», K.,1961, p. 175.

I. Micko, T. Paslavskij, «Yurij-Franc Kulchickij-geroj oboroni Vidnya», Lviv, 2013, p.38.

K. Harlampovich, «Listuvannya zaporozkih kozakiv iz sultanom», Zapiski Istorichno-filologichnogo viddilu VUAN, K.,1923, Kn. IV, p.200 - 212.

Letopis Ekaterinoslavskoj uchenoj arhivnoj komissii, Ekaterinoslav,1911, Vyp.7, p.113-116.

M. Kagan, «Legendarnyj cikl gramot tureckogo sultana k evropejskim gosudaryam - publicisticheskoe proizvedenie vtoroj poloviny XVII V.», Trudy otdela drevnerusskoj literatury Instituta literatury AN SSSR, Moskva, 1959, T.15. p.249 - 250.

M. Kagan, «Russkaya versiya 70-h godov XVII v. perepiski zaporozhskih kazakov s tureckim sultanom», Trudy otdela drevnerusskoj literatury Instituta literatury AN SSSR, Moskva,1958, T.14, p.307 - 315.

M. Kagan-Tarkovskaya, «Perepiska zaporozhskih i chigirinskih kazakov s tureckim sultanom (v variantah XVIII v.)», Trudy ODRK Pushkinskogo Doma, AN SSSR, M-Leningrad, 1966, T. XXI, p.346 - 354.

Mayak, SPb.,1845, T.22, Smes, p.112 - 113.

N. Markevich, «Istoriya Malorossii», Moskva, 1843, T.V.

Russkaia starina, SPb.,1872, T.VI, p. 450 - 451.

S. Velichko, «Letopis sobytij v Yugo-zapadnoj Rossii v XVII v», K.,1848, p.3 - 5 (Prilozhenie).

"Sobranie raznyh zapisok i sochinenij, sluzhashih $k$ dostavleniyu polnogo svedeniya o zhizni i deyaniyah Petra Velikogo», Izd. F. Tumanskim, Cpb.,1787, Ch.VII. p.161 - 163.

T. Chuhlib, «Viden 1683. Ukrayina-Rus u bitvi za «zolote yabluko» Yevropi», K.,2013, p.560.

«Tisyacha rokiv ukrayinskoyi suspilno-politichnoyi dumki. U 9-ti tomah», K.,2001, T.2. 